\title{
ENVOLVIMENTO DO PAI NO PERÍODO PRÉNATAL: REVISÃO INTEGRATIVA
}

Participación del padre en el período prénatal: revisión integrativa Involvement of the father in the prenatal period: integrative review

\author{
Joana Magalhães ${ }^{*}$, Germano Couto $^{* *}$, Carla Fernandes ${ }^{* * *}$, Isabel Oliveira ${ }^{* * *}$
}

\section{RESUMO}

Enquadramento: existem, atualmente, mudanças paradigmáticas em relação ao foco da enfermagem em saúde materna, sendo o papel predominante do pai um dos principais focos do cuidado. Objetivo: identificar a importância dada ao pai e o seu papel durante a gravidez. Metodologia: realizada uma revisão integrativa nas bases de dados CINAHL ${ }^{\circledR}$, Medline ${ }^{\circledR}$ e Psychology and Behavioral Science ${ }^{\circledR}$. Dos 601 artigos obtidos apenas 10 foram incluídos nesta revisão. Resultados: os artigos incluídos aludem para a gravidez como um período exigente, sendo considerado como uma transição para a paternidade. Da análise emergiram quatro subáreas: a representação mental do pai; como a gravidez se torna real para o pai; a maneira como os pais se comprometeram com a paternidade e o papel do pai na vida familiar. Conclusão: os resultados evidenciam a importância do pai durante a gestação e a necessidade emergente de centrar o cuidado na família diante de uma transição. A participação e inclusão do pai durante a gravidez desempenha um papel fundamental aumentando a confiança e conduzindo a uma melhor gestão do stress causado pela transição para a parentalidade de todos os membros da família.

Palavras-chave: Pai; Gravidez; Papel; Paternidade.

"Nurse

University Fernando Pessoa (PASOP), Porto,

Portugal

${ }^{* *}$ Associate Professor

Universidade Fernando Pessoa, Porto,

Portugal

Auxiliary Professor

University Fernando Pessoa, Porto, Portugal Specialist Professor

Escola Superior de Saúde Norte da Cruz Vermelha Portuguesa, Oliveira de Azeméis, Portugal
Como Referenciar:

Magalhães, j., Couto, G., Fernandes, C. Oliveira, I. (2018). Envolvimento do pai no período prénatal: revisão integrativa Revista de Investigação \& Inovação em Saúde, 2(1), 53-65
Recebido para publicação em:18/10/2018 Aceite para publicação em: 21/12/2018

\section{RESUMEN}

Framework: Existen actualmente cambios paradigmáticos en relación al foco de la enfermería en salud materna, siendo el papel predominante del padre uno de los principales focos del cuidado.Aim: Identificar la importancia dada al padre y su papel durante el embarazo. Metodología: Realizada una revisión integrativa en las bases de datos $\mathrm{CINAHL}^{\circledR}$, Medline ${ }^{\circledR}$ y Psychology and Behavioral Science ${ }^{\circledR}$. De los 601 artículos obtenidos apenas 10 se incluyeron. Resultados: Los artículos incluidos aluden al embarazo como un período exigente, siendo considerado como una transición a la paternidad. Del análisis surgieron cuatro subáreas: la representación mental del padre; como el embarazo se vuelve real para el padre; la manera como los padres se comprometieron con la paternidad y el papel del padre en la vida familiar. Conclusión: Los resultados evidencian la importancia del padre durante la gestación y la necesidad emergente de centrar el cuidado en la familia ante una transición. La participación e inclusión del padre durante el embarazo desempeña un papel fundamental aumentando la confianza y conduciendo a una mejor gestión del estrés causado por la transición a la parentalidad de todos los miembros de la familia.

Palabras clave: Padre; Embarazo; Rol; Paternidad.

\section{ABSTRACT}

Framework: There are currently paradigmatic changes in relation to the focus of maternal health nursing, with the predominant role of the father being one of the main focuses of care. Objective: To identify the father's importance and his role during pregnancy. Methodology: An integrative review was performed on the $\mathrm{CINAHL}^{\circledR}$, Medline $^{\circledR}$ and Psychology and Behavioral Science ${ }^{\circledR}$ databases. Of the 601 articles obtained only 10 were included in this review. Results: The included articles allude to pregnancy as a demanding period, being considered as a transition to paternity. From the analysis four subareas emerged: the father's mental representation; how pregnancy becomes real to the father; the way parents have committed to fatherhood and the father's role father in family life. Conclusion: The results highlight the father's importance during pregnancy and the emerging need to focus care in the family in the face of a transition. Father's involvement and inclusion during pregnancy plays a key role in building trust and leading to better management of stress caused by the transition to parenting of all family members.

Keywords: Fathers; Pregnancy; Role; Paternity. 


\section{INTRODUCTION}

There is a wide range of research focused on women's transition during the pregnancy period, as well as its importance (Tamis-LeMonda \& McFadden, 2010). Research around the paternal figure began to emerge in the 1980's (Silverstein \& Auerbach, 1999). In this context, according to the authors, it has become preponderant to focus research on the father, since it still has poor visibility. This will allow understanding the impact of the father's involvement during pregnancy.

Pregnancy determines a transition from a family of two for a family of three persons, one of the most important stages in the family life cycle (Linn, Wilson \& Fako, 2015). Throughout pregnancy, parents question their abilities because they do not know if they will be able to meet their own expectations (Hildingsson, Haines, Johansson, Rubertsson \& Fenwick, 2014). Fathers are a cornerstone in supporting women throughout this period, being fundamental their involvement so that, in the future, the bonds established with the child become stronger (Linn et al. Halle et al., 2016). Thus, understanding the father, despite all the difficulties and barriers experienced at this stage, is preponderant for the development of a happy and united family (Sansiriphun et al., 2010).

According to Poh, Koh \& Seow (2013) understanding this phenomenon lies at the genesis of what it is to be a nurse, directing care in the best possible way. However, what evidence is there available about the father's importance during pregnancy? Nowadays, several fields of knowledge have been studying this transition process and throughout this review of literature, it is expected to find the primordial aspects on the subject.

Thus, this article has as object of study the father, especially the importance attributed to the father and his role during pregnancy. The objective of this review is to identify the father's importance and his role during pregnancy.

\section{BACKGROUND / THEORETICAL BACKGROUND}

Over time the father's role has undergone changes, a result of the demands imposed by society. Once, paternity became more intense after birth, nowadays a father has become an educator and more participatory during pregnancy. In an industrial prerevolution perspective, the father was seen as authoritarian and responsible for the well-being of the family, namely at the economic level; he was the only one who worked, and agriculture was his means of subsistence. He supported the family, since they were numerous and lived in rural communities. From the eighteenth century until the mid-twentieth century, the traditional family ceased to exist and stopped relying on the support of family and friends to sustain themselves, as innovations in agriculture and industrial technology emerged (Linn et al., 2015). The city's growth process accelerated, so the indigence of the labor force in the industries and the decrease of workers in the field, promoted the exit of families from rural to urban environment. In fact, and as Benokraitis (2007) argues, people left behind dependent family and elderly parents as they became financial burdens. According to Cherlin (2004), associated to the economic evolution, there were improvements in the public and individual health due to changes in the quality of life, in hygiene 
habits and in diet. Thus, the woman was excluded from society, as she was not allowed to vote, to attend school, to own a real estate property or to manage her independence. In this line of thought, the woman was seen as a subordinated, only controlling pregnancy and childbirth. According to Beck \& Beck-Gursheim (as cited in Linn et al., 2015), with the industry growth a new movement emerged giving birth to the independent woman. Children who were only seen as a profitable family instrument, acquire a preponderant role in the couple's life, meaning that the woman stops focusing on domestic and family life assuming a role of a woman who invests in her professional career, in her family and in herself. On the other hand, the father leaves his main focus, work, focusing not only on his professional life, but also supporting the woman in the domestic activities and actively participating in the children's education, love and affection. In this way, one can consider that the couple is going through a process of developing new roles, moving from a dyad to a triad, which is, developing their affective and daily relationships, transforming them into a family alliance. According to the same author, fathers participate increasingly in domestic activities, as well as in child care. Also, according to Silva \& Lopes (as cited in Néne, Marques \& Batista, 2016, p. 71), "It has become culturally accepted that man becomes involved and pregnant from the psychological point of view." However, Marques argued that despite the fact that they do not go through the various transitions and sensations experienced in the woman's body, the father acquires a satisfactory involvement with the fetus, considering pregnancy as the foundation stone to establish and strengthen the existing interactions with the future baby (as cited in Néné et al., 2016).

During pregnancy, fathers question their abilities because they do not know if they will be able to meet their own expectations. According to Hildingsson et al. (2014), expectant fathers who are fearful of childbirth seem to have deteriorated health status in relation to those who do not have the same symptomatology. Men who exhibit this type of negative emotions are more likely to understand that pregnancy, childbirth and paternity are complex. Paternity presents significant stress in couples, threatening family functioning. Hildingsson et al., (2014) found that men experiencing high levels of fear in relation to childbirth are less positive, so fatherhood stress increases exponentially as they transit into parenting. This transition is a continuous working process, and depends on how men handle the other transformations, since there is a change in identity, which forces it to be redefined. It is important for men to internalize various roles ranging from son, husband, brother, friend, man, professional to father, that often question their masculinity. According to Marques, (as cited in Néne et al., 2016, p. 71), "This new role can awaken insecurities, given the greatness of the challenge ahead." Fatherhood entails relevant rights and obligations at the family level. Father's involvement during the pregnancy period has a positive impact on the whole family's health.

According to Lowdermilk \& Perry (2008), some men positively appreciate the father's role during pregnancy, being their main focus the response to the pregnant woman's feelings of fragility. Being directly involved with the pregnancy increases the 
bonds with the future baby when they caress the woman's abdomen, kiss, call the fetus by its name, play or communicate with it. Despite that, during pregnancy, some men feel a rivalry, although unconscious, that they expressed through small behaviors, providing a feeling of discomfort, since the woman has a more introspective attitude. In the same way, when observing the involvement of the woman with the pregnancy, they may feel misunderstood by taking refuge in new hobbies or by being deeply involved in their work. At the same time, there is a deficit accessing information, with significant consequences, since there are couples who are unaware of the changes that they face during pregnancy, the feelings that emerge during this process, as well as the best strategies to promote a healthy transition. Nurses who accompany parents during pregnancy and postpartum help minimize fears and maximize information that pertains to the entire process of parenting. Therefore, an integrative review was conducted to identify the importance given to the father and his role during pregnancy.

\section{METHODOLOGY}

To answer the main purpose of this research, a critical and extensive analysis of a set of existing publications on the topic was analysed, according to the methodological process for an integrative review (Souza, Silva \& Carvalho, 2010). After identifying the area of interest and selecting the research question, the inclusion and exclusion criteria were defined. The inclusion criteria were defined as primary scientific articles that particularize the father's role during pregnancy. This research was then conducted with no time limitations. In addition, all articles written in English and available in full text were included. Exclusion criteria were review articles, editorials, narratives, chapters and opinion articles, as well as articles not available, those focusing adolescent pregnancy, and those that did not answer to the research question. The research was conducted between November of 2017 and July of 2018 and 601 articles retrieved from databases. Data were collected by two independent researchers, which ensured the quality of the selected articles, from the following data bases:CINAHL ${ }^{\circledR}, \quad$ Medline ${ }^{\circledR} \quad$ y Psychology and Behavioral Science ${ }^{\circledR}$. . The descriptors used, in conjunction with the boolean operators AND, OR, are shown in Table 1. 
Tabela1

Boolean descriptons and markers used in the database search

\begin{tabular}{|c|c|}
\hline Data base & in descriptors and markers used \\
\hline CINAHL & 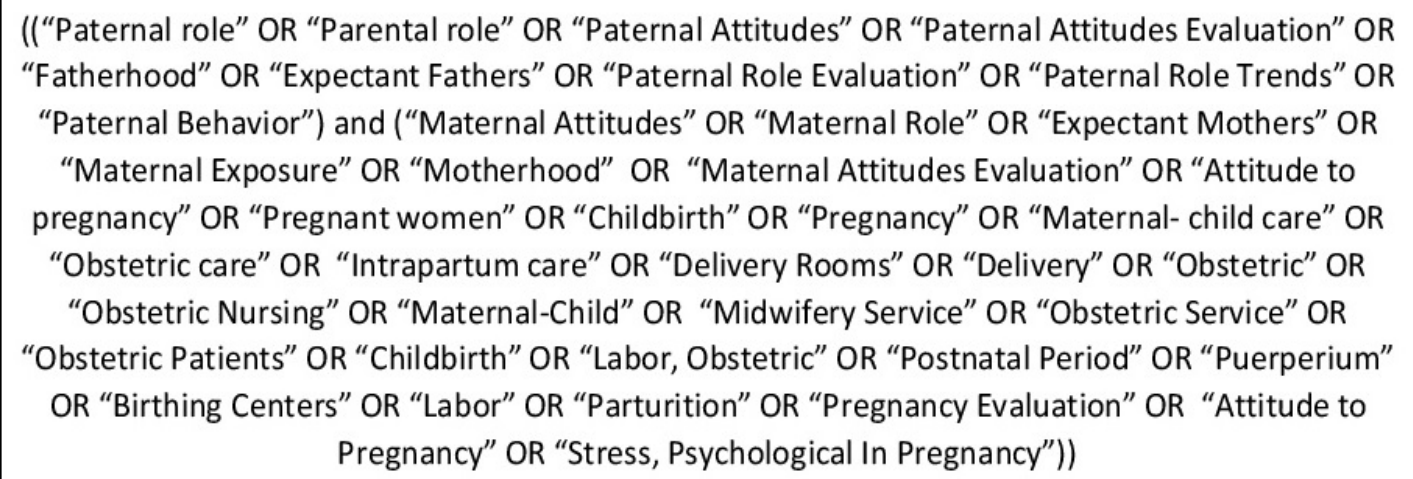 \\
\hline Medline & 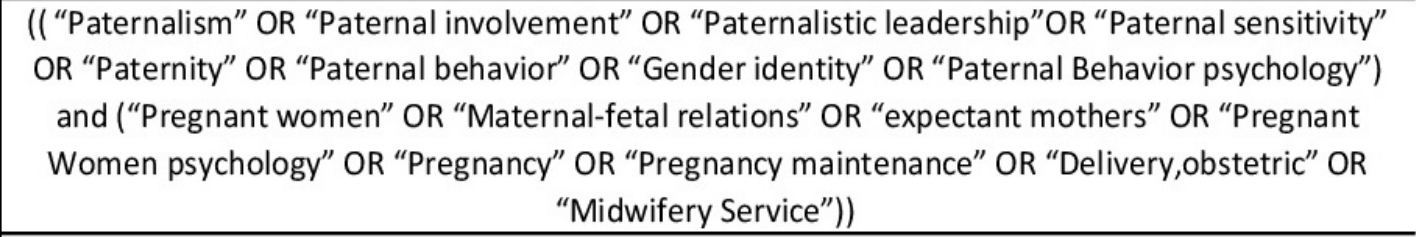 \\
\hline $\begin{array}{c}\text { Psychology } \\
\text { and } \\
\text { Behavioral } \\
\text { Science }\end{array}$ & 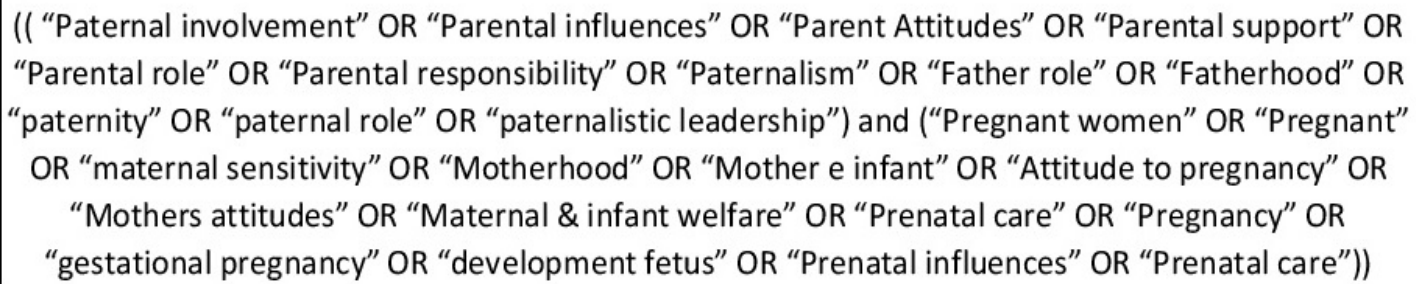 \\
\hline
\end{tabular}

Articles were excluded by repetition, title and abstract and full text analysis. The remaining articles were excluded because they did not answer the research question $(n=54)$ because they were unavailable $(n=12)$, because they were secondary research $(n=21)$ and because they focused on teenage pregnancy $(n=18)$, resulting in 10 studies for review, which are cataloged from E1 to E10. The Prisma Diagram Flow (Moher et al., 2015) shows the main step in the search developed for this review (Fig. 1). From the analysis of the studies, four subtopics emerged: the father's mental representation; the father's role in the family life; the father's commitment to fatherhood; and when the pregnancy becomes real for the father. 

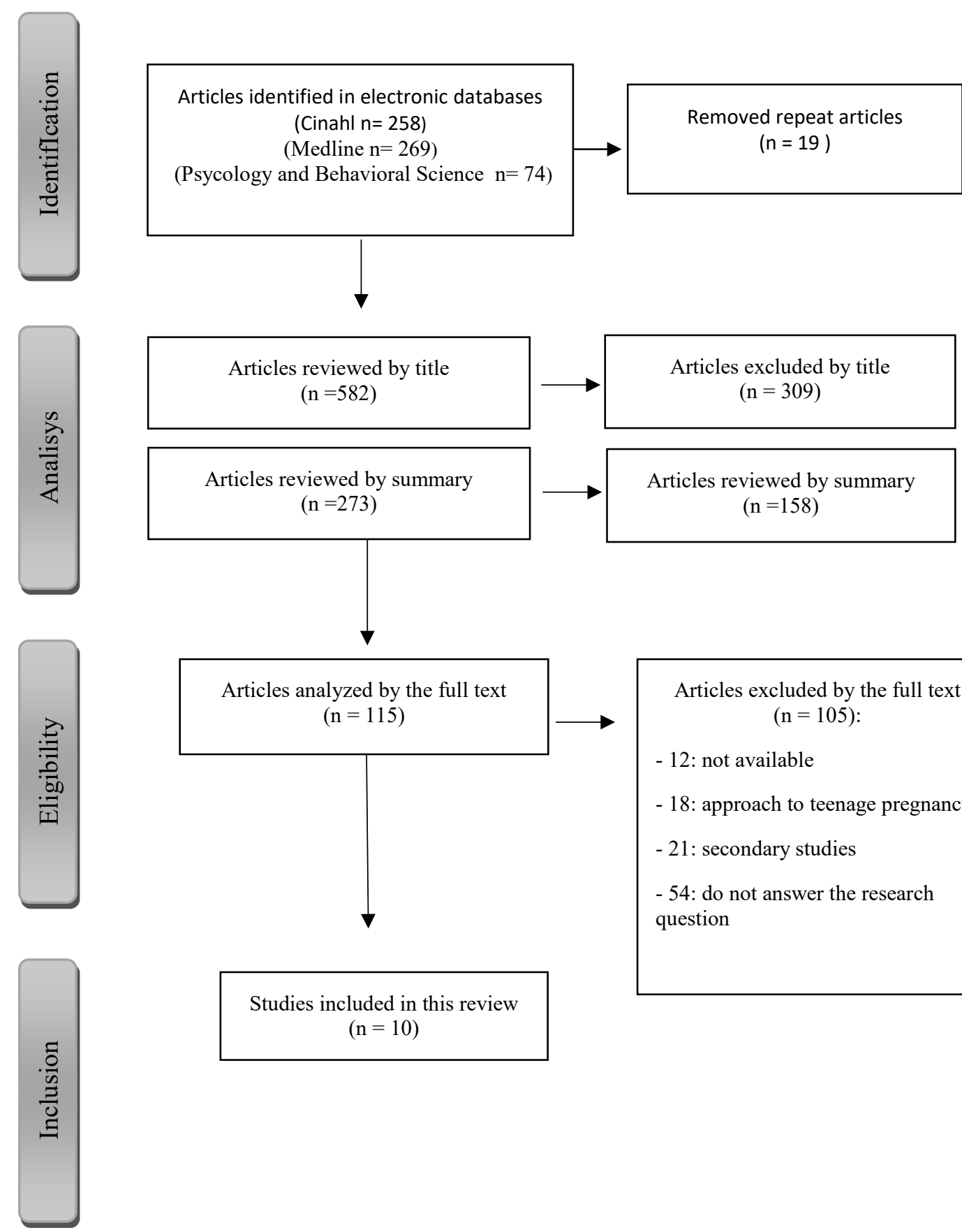

Studies included in this review $(\mathrm{n}=10)$

\section{Figure 1}

Process of identification and inclusion of studies - PRISMA Diagram flow.

\section{RESULTS AND DISCUSSION}

The data extracted from the included studies is summarized in Table 2, with the following information: code, reference, year, country of study, objective and type of study.

The largest number of studies is centered after the year 2010, and there are only three studies in the previous years. The majority of studies, with the 
exception of E9, were published in specific nursing journals. Concerning the country of publication of the articles, there is a great variety, one of the articles was published in Taiwan, two in the United States of America and the rest are condensed in Europe. Regarding methodology, seven qualitative studies and three quantitative studies were included. The sample varied from 11 individual participants to 827 couples, and one of the studies included seven health professionals. In this integrative review, the data analysis was performed with methodological rigor so that, starting from the results of selected studies, the assimilation and arrangement of the main concepts can represent an essential contribution to clinical practice.

Table 2

Data extracted from the included studies

\begin{tabular}{|c|c|c|c|c|c|c|}
\hline Code & Reference & Year & $\begin{array}{l}\text { Country } \\
\text { of study }\end{array}$ & Objetive & Format study & Participants \\
\hline E1 & $\begin{array}{l}\text { Åsenhed, L., Kilstam, J., Alehagen, } \\
\text { S., \& Baggens, C. (2014). Becoming } \\
\text { a father is an emotional roller } \\
\text { coaster - an analysis of first-time } \\
\text { fathers' blogs. Journal Of Clinical } \\
\text { Nursing, 23(9/10), 1309-1317. }\end{array}$ & 2014 & Sweden & $\begin{array}{l}\text { To identify and describe } \\
\text { the process of paternity } \\
\text { during the gestation of } \\
\text { the partner between } \\
\text { expectant parents for the } \\
\text { first time }\end{array}$ & $\begin{array}{l}\text { Qualitative } \\
\text { Exploratory }\end{array}$ & $\mathrm{n}=11$ first time parents \\
\hline E2 & $\begin{array}{l}\text { Kao, C., \& Long, A. (2004). First- } \\
\text { time Taiwanese expectant fathers' } \\
\text { life experiences during the third } \\
\text { trimester of pregnancy. Journal Of } \\
\text { Nursing Research (Taiwan Nurses } \\
\text { Association), 12(1), 60-71. }\end{array}$ & 2004 & Taiwan & $\begin{array}{l}\text { To explore the life } \\
\text { experiences of first time } \\
14 \text { expectant fathers } \\
\text { from Taiwan's while their } \\
\text { wives were in the third } \\
\text { trimester of pregnancy. }\end{array}$ & $\begin{array}{l}\text { Qualitative } \\
\text { Content } \\
\text { Analysis } \\
\text { Descriptive } \\
\text { phenomenologi } \\
\text { cal study; } \\
\text { Retrospective; } \\
\text { Cross-sectional }\end{array}$ & $\begin{array}{l}\mathrm{n}=14 \\
\text { First time expectant } \\
\text { fathers in Taiwan, while } \\
\text { their wives were in the } \\
\text { third trimester of } \\
\text { pregnancy. }\end{array}$ \\
\hline E3 & $\begin{array}{l}\text { Jordan, P. (1990). Laboring for } \\
\text { relevance: expectant and new } \\
\text { fatherhood. Nursing } \\
\text { Research, 39(1), 11-16. }\end{array}$ & 1990 & USA & $\begin{array}{l}\text { To describe the } \\
\text { experience of expectation } \\
\text { of new fatherhood. }\end{array}$ & $\begin{array}{l}\text { Qualitative } \\
\text { longitudinal, } \\
\text { explanatory, } \\
\text { descriptive, } \\
\text { correlational }\end{array}$ & $\begin{array}{l}\mathrm{n}=56 \text { expectant fathers } \\
\text { and first time recent } \\
\text { fathers living with their } \\
\text { lifemates. These were } \\
\text { between the ages of } 20 \\
\text { and } 41 \text { years old. }\end{array}$ \\
\hline E4 & $\begin{array}{l}\text { Rosich-Medina, A., \& Shetty, A. } \\
\text { (2007). Paternal experiences of } \\
\text { pregnancy and labour. British } \\
\text { Journal Of Midwifery, 15(2), 66- } \\
70 .\end{array}$ & 2007 & Scotland & $\begin{array}{l}\text { To evaluate the first } \\
\text { experiences of fathers } \\
\text { during pregnancy and } \\
\text { compare the experiences } \\
\text { of work between three } \\
\text { different modes of } \\
\text { childbirth }\end{array}$ & $\begin{array}{l}\text { Qualitative } \\
\text { longitudinal, } \\
\text { explanatory, } \\
\text { descriptive, } \\
\text { correlational }\end{array}$ & $\begin{array}{l}\mathrm{n}=142 \text { fathers who } \\
\text { decided to participate in } \\
\text { the study. } \\
\text { There are } 59 \text { parents in } \\
\text { the SVD group } \\
\text { (spontaneous vaginal } \\
\text { delivery), } 69 \text { parents in } \\
\text { the emergency group and } \\
14 \text { parents in the normal } \\
\text { delivery group. }\end{array}$ \\
\hline E5 & $\begin{array}{l}\text { Bogren Jungmarker, E., Lindgren, } \\
\text { H., \& Hildingsson, I. (2010). } \\
\text { Playing Second Fiddle Is Okay- } \\
\text { Swedish Fathers' Experiences of } \\
\text { Prenatal Care. Journal Of } \\
\text { Midwifery \& Women's } \\
\text { Health, 55(5), 421-429 }\end{array}$ & 2010 & Sweden & $\begin{array}{l}\text { To describe the } \\
\text { experiences of expectant } \\
\text { fathers and involvement } \\
\text { in prenatal care. }\end{array}$ & $\begin{array}{l}\text { Quantitative } \\
\text { Prospective, } \\
\text { longitudinal, } \\
\text { descriptive }\end{array}$ & $\begin{array}{l}\mathrm{n}=827 \text { couples } \\
\text { participated in the study } \\
\text { after exclusion of } \\
\text { abortions, stillbirths, } \\
\text { fathers who moved, } \\
\text { separated or who } \\
\text { withdrew from the study. } \\
\text { To be included in this } \\
\text { specific study, parents } \\
\text { must have completed all } \\
\text { three questionnaires. }\end{array}$ \\
\hline
\end{tabular}




\begin{tabular}{|c|c|c|c|c|c|c|}
\hline E6 & $\begin{array}{l}\text { Lewis, S., Lee, A., \& Simkhada, P. } \\
\text { (2015). The role of husbands in } \\
\text { maternal health and safe } \\
\text { childbirth in rural Nepal: a } \\
\text { qualitative study. BMC Pregnancy } \\
\text { \& Childbirth, 15(1), } 162 .\end{array}$ & 2015 & Nepal & $\begin{array}{l}\text { To examine the role of } \\
\text { husbands in maternity } \\
\text { care and childbirth safety, } \\
\text { their perceptions of } \\
\text { women and children } \\
\text { needs, the factors that } \\
\text { influence or discourage } \\
\text { their participation as a } \\
\text { father, and how women } \\
\text { feel about male } \\
\text { involvement in childbirth. }\end{array}$ & $\begin{array}{l}\text { Qualitative } \\
\text { cross-sectional }\end{array}$ & $\begin{array}{l}\mathrm{n}=42 \text { with } 35 \text { home } \\
\text { interviews being } \\
\text { delivered, including } 17 \\
\text { fathers, } 15 \text { mothers and } \\
\text { three mothers-in-law. } \\
\text { Seven interviews with } \\
\text { health professionals. }\end{array}$ \\
\hline E7 & $\begin{array}{l}\text { Widarsson, M., Engström, G., } \\
\text { Tydén, T., Lundberg, P., \& } \\
\text { Hammar, L. M. } \\
\text { (2015). 'Paddling upstream': } \\
\text { Fathers' involvement during } \\
\text { pregnancy as } \\
\text { described by expectant fathers } \\
\text { and mothers. Journal Of Clinical } \\
\text { Nursing, } \\
\text { 24(7-8), 1059-1068. }\end{array}$ & 2015 & Sweden & $\begin{array}{l}\text { Describe the perspectives } \\
\text { of pregnant women and } \\
\text { fathers on their } \\
\text { involvement during } \\
\text { pregnancy. }\end{array}$ & & $\begin{array}{l}\mathrm{n}=30 \text { expectant parents, } \\
\text { being } 20 \text { women and } 10 \\
\text { men. Of this total, } 20 \\
\text { were parents for the first } \\
\text { time ( } 12 \text { women and } 8 \\
\text { men). Participants were } \\
\text { between the ages of } 21 \\
\text { and } 56 .\end{array}$ \\
\hline E8 & $\begin{array}{l}\text { Straughen, J. K., Caldwell, C. H., } \\
\text { Young, A. J., \& Misra, D. P. (2013). } \\
\text { Partner support in a cohort of } \\
\text { African American families and its } \\
\text { influence on pregnancy outcomes } \\
\text { and prenatal health behaviors. } \\
\text { BMC } \\
\text { Pregnancy And Childbirth, } 13187 .\end{array}$ & 2013 & USA & $\begin{array}{l}\text { It was examined how two } \\
\text { indicators of partner } \\
\text { involvement, type of } \\
\text { relationship and parental } \\
\text { support, influenced the } \\
\text { risk of pregnancy } \\
\text { outcomes (preterm birth, } \\
\text { low birth weight) and } \\
\text { health behaviors } \\
\text { (prenatal, drug use and } \\
\text { smoking) among women } \\
\text { African American women. }\end{array}$ & $\begin{array}{l}\text { Quantitative, } \\
\text { descriptive and } \\
\text { correlational }\end{array}$ & $\begin{array}{l}\mathrm{n}=713 \text { women, resulted } \\
\text { after the following } \\
\text { exclusion criteria: } \\
\text { prematurity, low birth } \\
\text { weight, adequate prenatal } \\
\text { care, prenatal smoking } \\
\text { and prenatal drug use. }\end{array}$ \\
\hline E9 & $\begin{array}{l}\text { Kuljanić, K., Dorčić, T. M., } \\
\text { Bistrović, I. L., \& Brnčić-Fischer, A. } \\
\text { (2016). Prospective Fathers: } \\
\text { Psychosocial Adaptation and } \\
\text { Involvement in } \\
\text { the Last Trimester of Pregnancy. } \\
\text { Psychiatria Danubina, 28(4), 386- } \\
\text { 394. }\end{array}$ & 2016 & Croatia & $\begin{array}{l}\text { To test differences in } \\
\text { parental involvement in } \\
\text { pregnancy, detected } \\
\text { stress and quality of } \\
\text { relationships in relation } \\
\text { to complications during } \\
\text { pregnancy and during } \\
\text { pregnancy (gestational } \\
\text { weeks) in the last } \\
\text { trimester of pregnancy. }\end{array}$ & $\begin{array}{l}\text { Descriptive } \\
\text { quantitative } \\
\text { longitudinal } \\
\text { correlational }\end{array}$ & $\begin{array}{l}\mathrm{n}=143 \text { male sample of } \\
\text { first-time parents, aged } \\
\text { over } 18 \text { years, who } \\
\text { accompanied the } \\
\text { pregnant partner. }\end{array}$ \\
\hline E10 & $\begin{array}{l}\text { Johnsen, H., Stenback, P., Halldén, } \\
\text { B., Crang Svalenius, E., \& Persson, } \\
\text { E. K. (2017). Nordic fathers' } \\
\text { willingness to participate during } \\
\text { pregnancy. Journal Of } \\
\text { Reproductive \& Infant } \\
\text { Psychology, 35(3), 223-235. }\end{array}$ & 2017 & $\begin{array}{l}\text { Dinama } \\
\mathrm{k}, \\
\text { Finland } \\
\text { and } \\
\text { Sweden }\end{array}$ & $\begin{array}{l}\text { To clarify the experiences } \\
\text { of parents for the first } \\
\text { time during pregnancy in } \\
\text { three Nordic countries. }\end{array}$ & $\begin{array}{l}\text { Qualitative } \\
\text { phenomenolog } \\
\text { y }\end{array}$ & $\begin{array}{l}n=31 \text { parents were } \\
\text { recruited when the } \\
\text { partner was in the 30th } \\
\text { week of pregnancy or } \\
\text { more. The ages of the } \\
\text { parents ranged from } 24 \text { to } \\
43 \text { years. }\end{array}$ \\
\hline
\end{tabular}

As previously mentioned and after the review of the present articles on the father's involvement in the prenatal period, it is clear that pregnancy is a demanding period and is considered a transition to fatherhood [E1]. Parents make this commitment and show interest [E5]. These studies support the knowledge gained about how male bond to their partner / woman and the fetus / child can have a positive effect. Thus, four subtopics emerge from the main subject: father's mental representation [E1; E2; E3; E6; E7; E9; E10], when pregnancy becomes real for the father [E3; E4; E7; E9; E10], father's commitment to fatherhood [E1; E2; E3; E5; E6; E7; E9; E10], and the role of parents in family life [E1; E2; E4; E5; E6; E7; E8; E9; E10].

Father's mental representation 
Initially, one of the main issues referred to, goes through the way parents are daily confronted with various negative feelings such as frustration; such as health professional's negligence [E1]; fear, not knowing how to interact with the newborn; panic because they do not know how to proceed during labor, or how to respond to the various situations as a father [E2]; loneliness, since only the pregnant woman experiences alterations in the body consequences that come from pregnancy [E3; E1] health professionals, responsible for the support in the couple's life transition often put on the mother the focus of their attention, forgetting about the repercussions caused in the father, that is, the family is seen in part and not as a whole [E7].

However, it is now known that there are even physiological symptoms experienced by the father, such as insomnia, extreme fatigue, weight gain, nausea and back pain [E1]. Thus, studies report that the father's health is closely related to the bond felt by the baby. But if this is known today, why is there still a deficit in integrating fathers in the professional care [E7]?

The father feels alone during pregnancy and unable to achieve the role of idealized father [E3], experiencing a wide range of obstacles throughout pregnancy, barriers that can often be bridged through support / teaching by those whose principal purpose is to educate. Transversal to all analyzed articles is this feeling of fear, fear of the unknown, not understanding the changes that are intrinsic to pregnancy, frustration about not knowing how to interact with their child, fear of misunderstanding mood changes and poor temperament women, sadness because they could not help the pregnant woman with the discomfort, ambitioning even the anticipated birth [E2]. Stress is the feeling that results from pressure and anxiety to the point of being unable to function properly physically and mentally. Thus, first time parents experience elevated levels of stress during the pregnancy period and their adaptation to fatherhood. These levels do not change at all if they experience a pregnancy with associated complications [E9]. However, different authors report that trained parents are more prepared to deal with unexpected situations [E10].

Thus, it is considered that the active participation and father's inclusion can be explained by the biopsychosocial model, ie, the increase of oxytocin plays a fundamental role in the couple's connection, mainly in the third trimester of pregnancy [E2, E9]. Fathers feel real excitement and happiness because they know the baby is coming. Also, study [E2] states that couples experience 4 different types of perception. When a woman becomes pregnant, she feels that her obligations towards her family are fulfilled, and that one of her greatest goals is to have a baby. As the life goal is achieved, he sees how his wife's discomfort is over and sees the beginning of a new era full of love and affection that unites them forever, wich began with the conception of the fetus and "carrying the child in the womb."

It can then be deduced that the internal and external pressure that parents feel during pregnancy contributes to pejorative feelings, in this way, it is up to the health professionals to integrate parents in care, increasing their confidence. That is, the parents start to live a pregnancy with fewer complications 
and better manage the stress caused by this transition, eventually becoming grateful to health care professionals.

\section{PREGNANCY BECOMES REAL}

At first the father sees the pregnancy as the woman being sick or just gaining weight, eventually hypothesizing [E9]. However, from the moment he hears the baby's heart, when he watches the ultrasound, he stops thinking about the woman in this way and begins to feel more and more involved in the pregnancy [E3, E4, E7, E10]. As the father feels the baby, it makes his existence more understandable. In this way, it is understood that the technologies and the new techniques promote a more real perception of the pregnancy for the father, helping him to cross for one of the major transitions of life, because he is putten in a situation in which he may feel total lack of control. However over time, this transition is overcomed.

\section{Father's commitment to paternity}

Throughout pregnancy, parents increasingly want to get involved in pregnancy. They are committed to counseling with experienced people, attending training courses, and retraining their childhood to become better fathers and husbands [E1, E2, E3, E5]. Thus, they aspire to have an active role in pregnancy. However, they question their capacities for fear of failing to live up to their own expectations, stating that the information they receive is not always sufficient $[E 1, E 5]$. In order to reduce these difficulties, they commit themselves to making savings, so that the child has the best possible future, to become involved in the pregnancy process by putting aside preconceptions and old traditions [E2, E6, E10]. Today it is known that the more active and involved parents are in pregnancy and childbirth, the better the relationship between them and their wives will be, as well as co-parenting [E7, E9, E10]. There is also a difference between parents for the first time, of those who have children, because they give a different importance to the information they receive [E5]. In the same line of thought, it can also be mentioned that parents are less likely to follow the same steps as their parents, that flexibility and adaptation to new situations and values is closely linked with the involvement of pregnancy [E9, E10].

\section{Role of parents in family life}

Expectant fathers are aware of their role, perceiving that this is different from that of their partners, because during the pregnancy period, they are mere observers, beginning to have physical contact with the baby after birth. They have matured through their experience during pregnancy succeeding thoughts and feelings about the life that will come [E2]. Therefore, becoming a parent is a priority in which the focus is off-centered and directed towards the baby, that is, it is redirected to the new family and as a consequence the relationship with the partner can improve [E1]. A desired pregnancy enables positive paternal involvement during pregnancy and postpartum [E9], since it is more real, they become fully involved throughout their process [E4]. Today, couples agree that prospective parents should become more involved in pregnancy, reflecting a change in the social mentality [E6]. Pregnancy admits different interpretations, since the 
quality of the relationship influences it positively [E9], promoting beneficial effects on the whole family's health [E7]. However, other authors report that the type of relationship / involvement of the partner does not compromise the pregnant woman's health [E8].

The transition to fatherhood triggers feelings of uncertainty, therefore, they try to do their best to adapt, establishing strategies to overcome them [E2]. Stress is perceived by a parent as a negative factor, since it reduces the involvement of the pregnancy, which may even be triggered by inadequate communication between the couple, overloading the woman in both domestic and unpaid work, thus damaging the family's health as a whole [E7]. On the other hand, it can be understood as a positive factor because, when intimately involved in pregnancy and exposed to high levels of associated stress, they increase the quality of the relationship [E9].

The father is the best support for the mother during pregnancy. The goal is to create ideal conditions for both mother and baby [E7], showing concern predominantly in the third trimester of pregnancy [E2]. Its presence is profoundly related to birth weight and prematurity [E8].

Prenatal care for the pregnant woman is considered to be of great relevance and satisfaction to parents. Fathers, when accepted by health professionals, interact more frequently with the family, that is, they feel more involved in the pregnancy process once they take on this responsibility, strengthening the relationship with the partner.

In short, over time the father's role in pregnancy has been changing. Increasingly it is seen as indispensable in the involvement with the mother and baby. In this way, the father, despite all the less positive feelings, difficulties and barriers, nowadays plays a shared role and is also the target of maternal and obstetrical health nursing care.

In nursing, looking at the family as a whole occupies a place of great importance, because care's excellence is intrinsically related to the experience of a healthy pregnancy and a parenting full of significant emotions.

In the genesis of the present review was the inevitable determination and curiosity to understand to what extent the father is important during the pregnancy. In this sense, a path of research and commitment was pursued which, in a general way, allowed answering the research question initially formulated. Of all the studies found and explored, 10 articles were selected for analysis. After being examined individually and finally discussed with the other bibliographical references, it is believed that it was possible to respond to the guiding objectives. It became pertinent, for analysis purpose, to group into subthemes: father's mental representation, pregnancy becomes real for the father, commitment of the father with the fatherhood, role of the parents in the life of the family.

As far as the father's mental representation is concerned, it has been found that the father often feels fear and anxiety. However, at the same time, feelings of joy, occupy a primordial role in pregnancy. In this perspective of care nurses acquire a fundamental role that will help to overcome one of the major transitions of an adult's life. For, it assists, 
and educates techniques and strategies to adapt to fatherhood and therefore a healthy transition.

\section{CONCLUSION}

Father's involvement and inclusion during pregnancy plays a key role in building trust and leading to better management of stress caused by the transition to parenting of all family members. Research on the father's importance during pregnancy is a significant contribution for nurse's intervention in antenatal care, since their cooperation has great advantages, such as increased parental confidence and gratitude. When included in care, fathers end up being more involved in the pregnancy process. Thus, this study has brought to nursing several contributions, namely the importance of decentralizing mother's / baby's health care, focusing on the family as a whole and father's teaching / education, which is essential. It helps them so that they can achieve the role of idealized father. However, it also has an impact on society, denoting a change in attitudes and acceptance of the divergence of the parent's role.

In the course of the research, it is pertinent to highlight the following limitations, namely in the search of studies that provide a more effective response to the objectives initially proposed. To develop this review it was necessary to analyse numerous articles for selection and data extraction, with different methodological approaches, so that pertinent results could be compiled.

It is important to emphasize that the subject under study is very pertinent, and was for the authors a challenge and a motivation for the work developed. However, there is a need to develop more research and disseminate the results to parents and nurses, since there is little information on strategies that health professionals can adopt to help parents in the transition to fatherhood.

\section{BIBLIOGRAPHIC REFERENCES}

Åsenhed, L., Kilstam, J., Alehagen, S., \& Baggens, C. (2014). Becoming a father is an emotional roller coaster - an analysis of first-time fathers' blogs. Journal of Clinical Nursing. 23(9/10), 1309-1317.

Benokraitis, N. V. (2007). Marriages \& families: changes, choices, and constraints. Princeton, NJ: Prentice Hall.

Bogren Jungmarker, E., Lindgren, H., \& Hildingsson, I. (2010). Playing Second Fiddle Is Okay-Swedish Fathers' Experiences of Prenatal Care. Journal of Midwifery \& Women's Health. 55(5), 421-429

Cherlin, A. (2004). The deinstitutionalization of American marriage. Journal of Marriage and Family. 72, 403-419.

Halle, C., Dowd, T., Fowler, C., Rissel, K., Hennessy, K., MacNevin, R. \& Nelson, M. A. (2008). Supporting fathers in the transition to parenthood. Contemporary Nurse. 31:1, 57-70. doi:10.5172/conu.673.31.1.57.

Hildingsson, I., Haines, H., Johansson, M., Rubertsson, C. \& Fenwick, J. (2014). Childbirth fear in Swedish fathers is associated with parental stress as well as poor physical and mental health. Midwifery. 30(2):248-54. doi: 10.1016/j.midw.2013.12.012 .

Johnsen, H., Stenback, P., Halldén, B., Crang Svalenius, E., \& Persson, E. K. (2017). Nordic fathers' willingness to participate during pregnancy. Journal of Reproductive \& Infant Psychology. 35(3), 223-235.

Jordan, P. (1990). Laboring for relevance: expectant and new fatherhood. Nursing Research. 39(1), 11-16.

Kao, C., \& Long, A. (2004). First-time Taiwanese expectant fathers' life experiences during the third trimester of pregnancy. Journal of Nursing Research (Taiwan Nurses Association). 12(1), 60-71.

Kuljanić, K., Dorčić, T. M., Bistrović, I. L., \& Brnčić-Fischer, A. (2016). Prospective Fathers: Psychosocial Adaptation and Involvement

the Last Trimester of Pregnancy. Psychiatria Danubina. 28(4), 386-394.

Lewis, S., Lee, A., \& Simkhada, P. (2015). The role of husbands in maternal health and safe childbirth in rural Nepal: a qualitative study. BMC Pregnancy \& Childbirth. 15(1), 162.

Linn, J.; Wilson, D. \& Fako, T. (2015). Historical Role of the Father: Implications for Childbirth Education. International Journal of Childbirth Education, International Journal of Childbirth Education. 30 (1), 12-18.

Lowdermilk, D. \& Perry, S. (2008). Enfermagem na maternidade. Loures: Lusodidata. 
Marques, T. (2016). Aceitação e vivência da gravidez no casal. in Néné, M., Batista, M., \& Marques, R. (Ed.). Enfermagem de saúde materna e obstétrica. (1a ed.) Lisboa: Lidel.

Moher, D., Shamseer, L., Clarke, M., Ghersi, D., Liberati, A., Petticrew, M., ... Group, P.-P. (2015). Preferred Reporting Items for Systematic Review and Meta-Analysis Protocols (PRISMA-P) 2015 statement. Systematic Reviews, 4, 9. doi:10.1186/20464053-4-1

Poh, H., Koh, S. \& Seow, H. (2013). First-time fathers' experiences and needs during pregnancy and childbirth: A descriptive qualitative study. An International Journal Midwifery. 24 (3), 1-9. http://dx.doi.org/10.1016/j.midw.2013.10.002

Rosich-Medina, A., \& Shetty, A. (2007). Paternal experiences of pregnancy and labour. British Journal of Midwifery. 15(2), 66-70.

Sansiriphun, N., Kantaruksa, K., Klunklin, A., Boasuang, C. \& Jordan, P. (2010). Thai men becoming a first- time father. Nurs. Health Sci. 12, 403-409.

Schaurich, D. \& Crossetti, M. (2010). Produção do Conhecimento sobre Teorias de Enfermagem: análise de periódicos da área. Escola Anna Nery Revista de Enfermagem. 14, (1), 182-88. http://dx.doi.org/10.1590/S1414-81452010000100027.
Silva, M. \& Lopes, N. (2016). Comunicação Intrauterina. in Néné, M., Batista, M. \& Marques, R. (Ed.). Enfermagem de saúde materna e obstétrica. (1 1 ed.). Lisboa: Lidel.

Silverstein, L.; Auerbach, C. (1999). Deconstructing the essencial father. American Psychologist. 54, (6), 397-407.

Souza, M.; Silva, M. \& Carvalho, R. (2010). Revisão integrative: o que é e como fazer. Einstein. 8,(1 pt 1):102-108.

Straughen, J. K., Caldwell, C. H., Young, A. J., \& Misra, D. P. (2013).

Partner support in a cohort of African American families and its influence on pregnancy outcomes and prenatal health behaviors. BMC

Pregnancy And Childbirth, 13187.

Tamis-LeMonda, C. S., \& McFadden, K. E. (2010). Fathers from low-income backgrounds: Myths and evidence. in M. E. Lamb (Ed.). The role of the father in child development ( $5^{\text {th }}$ ed., 296318). Hoboken, NJ: John Wiley \& Sons.

Widarsson, M., Engström, G., Tydén, T., Lundberg, P., \& Hammar, L.

(2015). 'Paddling upstream': Fathers' involvement during pregnancy

described by expectant fathers and mothers. Journal Of Clinical Nursing.

24(7-8), 1059-1068. 